\title{
Lilla Młodzik
}

University of Zielona Góra, Poland

\section{The Common Good and Trust in Security Organisations}

Abstract

Modern organisations that are the object of research on security sciences do not remain unchanged over time. However, there are continual categories such as the common good and trust. The security world is not about whether stakeholders are more or less willing to trust other people, but about whether members of the organisation rely on trust, creating interpersonal relationships, in their activities, building a culture of security. Then the common good becomes less exposed to the effect of the "tragedy of the commons". Building the trust can, therefore, mitigate this effect. This fact is facilitated by the use of cooperative leadership style, by shaping values, norms and patterns cultivating the concern for "common good". The development of this issue is the subject of this paper.

Keywords: common good, public good, trust, leadership, management

Creating the English-language version of the journal "Securitologia" is financed under contract No. 724/PDUN/2018 from the funds allocated by the Minister of Science and Higher Education for dissemination of science. 


\section{Introduction - "tragedy of the commons"}

The essence of organisations operating in the sphere of security is the common good, as that which, regardless of the conditions, is associated with the absolute fulfilment of social needs through public goods, which must be provided to citizens due to the implementation of the essential functions of the state. A particular feature of public goods is not that the State provides it, but that the benefits of using them cannot be limited to just one person or one household. Pure public goods differ from private goods, according to Milewski (2006, p. 97) with two features: first of all, using them by one person does not exclude the use of them by other people. Secondly, when they are already provided, there is no possibility in practice to exclude anyone from using them. Public goods, therefore, bring considerable social benefits in comparison to private benefits, which makes them socially desirable.

On the other hand, as Sułkowski argues (2012), one should not forget about the essence of human nature with a tendency to compete, formed on the path of evolution. The author allegorically refers to the concept of "the strategy of the commons" (Hardin 1968), describing it as follows: Shepherds grazing sheep in a common meadow face the temptation to enlarge their herd, because, from the point of view of individual economic rationality, the optimal solution is to multiply their benefit. Enlarging the herds is hidden and gradual because the shepherds do not want to deliberately break the unwritten social contract or destroy the ecosystem of the meadow. However, they successively add one sheep to the herds and thus destroy the pasture.

"The tragedy of the commons" is a model of a broader social mechanism that leads to excessive exploitation and consequently the collapse of the "common good" (Sułkowski 2012, p. 10). In order to reduce or mitigate this effect, the author proposes shaping values, norms and patterns cultivating the concern for "common good", building trust through agreements, combined with an effective system of searching, sanctioning and punishing fraud, and to some extent the possibility of limiting areas of "common good", which can be more effectively managed and developed in private hands.

Therefore, there is a tendency to understand security as, among others a process that is inseparably existing with the state, which management “(...) is an organised activity carried out with the use of human, financial, technical and information resources to reduce potential threats, ensure unhindered social life, as well as to protect human life and health and property and the environment" (Sienkiewicz-Małyjurek, 2010, p. 127). 
The article highlights the category of trust - a component of the discussed process, which alleviates the phenomenon of "tragedy of the common good", the building of which should be based on the cooperative style of leadership occurring in public organizations operating for security (Młodzik 2018a) through the formation of values, norms and patterns cultivating the concern for "common good".

\section{The essence of trust}

There are many different definitions of trust. It is associated with faith, belief, and reliability (not to disappoint someone's trust), or distrust (which is an antonym of trust and not lack of trust), it can be a centre between dogmatism and criticism, it can be conditioned by personality, environment or relation, and it may be the contradistinction of suspicion. Trust seems particularly crucial in teamwork, severe situations and crises (Kożuch, Sienkiewicz-Małyjurek 2013). In the definitions of trust, there are categories of interdependence, sensitisation, and risk (Sankowska 2011). Trust can be treated as:

- action - behaviour,

- belief, which consists of three components: affective state (what we feel),

- cognitive state (what we think) and intended behaviour (how we intend to behave),

- decision or (and) intention combined with conviction. Self-belief does not have to be synonymous with an intention.

"Despite the proliferation of the definition of trust in literature, no common position has been developed" (Sankowska 2011, p. 30). Moreover, explaining such terms as "trust" in social sciences seems to be an infinite process (Babbie 2008). It is recognised, however, that it is crucial for "trust" to share common values (Grudzewski, Hejduk, Sankowska, Wańtuchowicz 2007; Zarzadzanie respektujace wartości. Raport z badań 2016).

When considering the various researches of authors in the area of identification of trust components, some convergence may be noted. Most of them refer to such values as honesty, kindness and competence (Sankowska 2011). "Integrity involves a reference to values, consistency in action, fulfilment of commitments and compatibility between declarations and actual actions, which ultimately influences the predictability of actions. Competence safeguards the effective achievement of the objectives. They are the result of collective learning, and over time they turn into organisational knowledge. Kindness, 
in turn, is based on shared principles, a sense of unity and willingness to cooperate" (Gadomska-Lila, 2017, p. 77).

The mentioned above trust components are most often grouped as follows (quoted after Sankowska 2011, pp. 39-40; Gadomska-Lila 2017, p. 77):

- Competence, predictability, honesty, kindness.

- Accessibility, competence, discretion, justice, honesty (righteousness), loyalty, openness, a realisation of promises, openness (to new ideas) as the opposite of dogmatism.

- Expert knowledge/competence, reliability, intentions.

- Competence, kindness, honesty.

- Ability, kindness, honesty.

- Kindness, reliability, competence, sincerity, openness.

- Competence, reliability, honesty, transparency, kindness, identification, reputation.

- Results, honesty, care.

- Care, openness and sincerity, identification, reliability, competence.

- Competence, honesty, openness.

In the group of values created by Oleksyn (2016) trust is included in the group of ethical and cultural values (alongside economic, managerial and competency and social values), including, apart from the discussed concept: dignity, respect, loyalty, responsibility, openness, integrity (including honesty), solidarity, justice, moderation, generosity, kindness. The author emphasises that the division into individual groups is not explicit, and the assignment to individual groups is controversial. However, such a proposal for a catalogue of values allows for a reference to ethical and cultural issues.

In the issue of trust as a whole or gradual category, both the first and second approaches can be found in the literature. According to Šmid (2003), there can be no other than total trust. Either one has them, according to the authors, or not.

The other approach is proposed by Sztompka (2007), who determines the gradation of trust on the type of expectations towards the other side.

1. Effective - relating to the instrumental properties of actions undertaken by partners:

a. an expectation of regularity, predictability, consistency, predictability in activities, 
b. an expectation of rationality in actions,

c. an expectation of competence, efficiency, productivity or effectiveness in activities.

2. Axiological - concerning the moral qualities of actions:

a. an expectation of responsibility, principledness, truthfulness, justice, dignity in actions.

3. Caring - "representative", "fiduciary" - related to activities:

a. an expectation of selflessness in taking care of the affairs of the partner, nobility, help, altruism.

This trust scale is correlated with the number of people in individual expectations groups. Most of them are on the first (effective) level, and then on each relatively less, up to the third - caring level, in which there are the least people According to Czajkowska (2014), this is related to the risk - the experience of a profession. As moving to a "higher" level, the risk of acting increases with the growing demands of the partners. This does not mean that there are no people - altruists, but there are certainly fewer of them. An indication of the existence of levels of trust should lead to its building from the discussed values. Indeed, it takes time, knowledge of ethics (trust is not credulity or naivety) and emotional maturity of all stakeholders of the process. These issues are fundamental in security organisations.

\section{Trust in security organisations}

The problem of trust was transferred from sociology to other sciences at the end of the 20th century (Sztompka 2005). This is connected, as the author and the creator of the synthetic theory of trust claims "with the shift of the accent to soft variables related to culture, collective mentality, moral bond, nuances of interpersonal relations" (Ibidem, p. 308). These elements were also adapted to the sciences of safety. In public organisations providing security ${ }^{1}$, trust has a unique dimension. It refers to their essence, i.e. serving society. How else to pursue this goal, if not by building relationships based on

\footnotetext{
${ }^{1}$ Organisations operating in the sphere of public affairs, having, on the one hand, features characteristic for all organisations, and on the other hand attributes specific to relations with citizens and the public interest and, in a narrower sense, the public service (Kożuch 2011).
} 
trust and other specific values that distinguish this type of organisation from the sphere of business? It seems that there is no other way.

Management by the trust (Ricci 2006) ${ }^{2}$ is neither about trusting nor about not trusting, but about knowing to what extent to trust (gradual category) and professionally building trust. In the sciences of security, as Filipek claims (2014, pp. 164-165), giving wise trust by a given subject leads to the creation of a security culture. However, there are many behaviours, mainly from the management, which in themselves are not conducive to building trust. In the case of public organisations, they are particularly important because, as Władek (2016) and Frackiewicz-Wronka (2015) conclude, the role of the top management in public organisations is of a particular nature, more complicated than in the private sector and is based on the dual responsibility borne by the superiors in the political and administrative spheres. According to researchers, there are many negative or even pathological phenomena in public organisations.

Kieżun (2005, pp. 375-376) distinguishes the "The Four Horsemen of the Apocalypse" - gigantomania, corruption, arrogance and luxury. Derdziuk and Obłuski (2008) even speak of anomie. Szaban (2011, pp. 58-59) lists the following sins of public organisations: politicisation, guardedness, cronyism and nepotism, limitation of the bottomup initiative, poor information flow between various levels of administration, insufficient competences of officials. These phenomena may relate, among others, to the adverse effects of distrust and other intangible resources that create a security culture.

As mentioned earlier, in the case of public organisations in the sphere of security, the most important is building trust based on the purpose of the organisation that is, serving the public, which is best reflected by the following dimensions of trust (Schindler, Thomas 1993, pp. 563-573): competence, consistency, loyalty, openness and righteousness. They are, among others, related to the term "profession of public trust", which is commonly used. On the one hand, an official (public officer) ${ }^{3}$ should be trustworthy, and on the other hand trust the citizen to get the trust in return. This requires compliance with specific rules of conduct. Public servants should set an example not only by professional life but also in the area of social relations.

\footnotetext{
${ }^{2}$ Kenn Ricci is a member of the aviation industry (and therefore a security organisation) and is the director of Directional Aviation Capital, the owner of various airlines, including Flexjet, Sentient Jet, Sky Jet, Nextant Aerospace, Stonebriar Commercial Finance, Reva Air Ambulance. His book Management by trust includes practical management techniques in building employee trust and success.

${ }^{3}$ Today, a public official (public officer) is in common sense - i.e. in great simplicity - everyone employed in a public organisation (Kulesza, Niziołek 2010).
} 
Unfortunately, this is a complicated process. This difficulty is determined by the modern picture of the world, in which hedonistic lifestyle and relationships based on the exchange of mutual benefits are increasingly important. It should be borne in mind that loss of trust can be tough to recover (Bibb, Kourdi 2004). This is evidenced by the results of the research (Zarzadzanie respektujace wartości. Raport z badan 2016, p. 48), which reveal the most drastic decline in the importance of trust in public sector organisations in Poland in the last three years. At the same time, 51\% of public sector respondents point to ethical values (including trust) as "important for the achievement of the mission, objectives and image of the organisation and the culture promoted, sufficiently exposed in the management system" (Ibidem, p. 25).

This contradiction may have the following explanation. Going beyond the comfort zone and empathic and subjective approach requires high maturity (emotional intelligence, a high degree of readiness to take responsibility for tasks, high professional skills) and a desire to apply the principles mentioned above starting with oneself. Moreover, according to the representatives of some public professions (services), improper ethical behaviour should be perceived and evaluated by their superiors, also through the prism of their own (leadership) attitudes (Ciborowski 2010).

On the other hand, however, it seems that among today's society there is a "hunger" of the aforementioned mutual trust in social relations, which include internal (group, intergroup) relations as well as external (official - citizen). As Barankiewicz claims (2013), there is no need to build anything new in this regard. Certain values (virtues) associated with trust are inscribed in the essence of the discussed public organisations (honesty, responsibility, kindness). Therefore, it is enough, according to the author, not to destroy what is already there.

\section{A cooperative leadership style based on trust}

The features and behavioural patterns (concerning trust) required from managers, concerning the service in the area of security, are usually determined on the occasion of distinguishing the so-called styles of managing people. In many arising typology proposals, various criteria apply: the way of dividing organisational power, the dominant type of stimuli used by the supervisor, the main subject of interest of the superior or 
the orientation on employees and / or tasks (Blake, Mouton 1964; Reddin 1970; Sims, Manz 1996).

In public organisations related to security, "the role of the leader due to their dual responsibility, both in the political and administrative sphere, is much more complicated than in the private sector" (Frączkiewicz-Wronka 2015, p. 127). Kożuch (2011) indicates that the leaders operating in the public sector distinguish themselves from those operating in the sphere of business by the system of values and the related general attitude to cooperation and specific competencies correlated with the listed elements. It is necessary to treat these observations as essential in the considered deliberations.

Brown (1962) believed that the role of the manager in cooperation was manifested in the democratic style of management he practiced (participating, cooperative, consultative), in such a way that, firstly, the manager encourages subordinates to cooperate with each other and facilitates it, and secondly, pursues a managerial role by interacting with them. "Shaping collaboration in a group involves influencing others to participate in a collective effort, helping the group in making decisions and minimising the supremacy of the position. The cooperation in performing the activity of managing the group is manifested in the democratic style of management" (Czerniawski 1982, p. 53).

Therefore, it can be assumed that the style of management in cooperation (cooperative style) may pose a particular variant of the democratic style, oriented both to officers and tasks, taking into account the maturity of the group (Likert 1976; Penc 2011; Hersey, Blanchard 1982).

Managers highly placed on the first scale (focused on people) care primarily about maintaining good interpersonal relations in the team, bilateral communication, mutual trust, and take into account the needs and aspirations of subordinates. They attach great importance to listening to their suggestions and providing them with favourable working conditions. They also take measures to clarify matters related to the objectives of the organisation.

Leaders located high on the second scale (task-oriented) pay particular attention to formal managerial functions, focus on task planning, order, predictability of effects, precise commands, determination of appropriate standards and procedures, subordination of the team's day-to-day instructions and deadlines, define its role and role of subordinates, primarily in terms of achieving the objectives of the organisation (Likert 
1976; Blake, Mouton 1964). The level of maturity of subordinates is categorised in the following simplified way (Hersey, Blanchard 1982):

a) low professional skills, a low readiness to assume responsibility for tasks (low self-confidence);

b) low professional skills, a high level of readiness to assume responsibility for tasks (high self-confidence);

c) high professional skills, a low degree of readiness to assume responsibility for tasks (low self-confidence);

d) high professional skills, a high degree of readiness to assume responsibility for tasks (high self-confidence).

The basic question to which a cooperation-oriented manager should seek answers is: To what extent can people under my authority work independently, without directives and incentives, and what can their maximum effectiveness be?

For the analysis, the following aspects of management styles, which allowed the author to distinguish a cooperative style based on mutual trust, were selected:

1. Focus on subordinates, preceding the focus on tasks 4 .

2. The degree of "maturity" of subordinates defined by two factors: an inclination to take responsibility and experience/skills related to their professional role.

\section{Summary}

The interdisciplinary nature of security sciences entitles their representatives to use various studies. Can the building of trust (sociological knowledge) and the cooperative style of management (management science) in discussed public organisations mitigate the effect of the "tragedy of a commons"? Are the security issues, the mission of service related to the concerned categories?

It seems so. On the other hand, public organisations must act following the logic of market processes and guidelines for efficient operation (Kotarbinski 1999), taking into account the principle of economic efficiency, although their key objectives are not such as commercial organisations. Indeed, the common good is not an intangible being, but

\footnotetext{
${ }^{4}$ Simplifying: orientation towards officers, which does not exclude focusing on tasks, since both variables are relatively independent (Blake, Mouton 1964, Likert 1976); the analysis attempted to agree on both orientations, not to polarise, using the approach of C.G. Jung (1997).
} 
a cultural structure based on trust. The theoretical analysis undertaken by the author results from the lack of existing research that seems necessary in this area. The most appropriate would be empirical analyses concerning ways of shaping culture based on the trust in the discussed organisations, which are a response to the problems of the present day. "The culture of trust can increase the effectiveness of the organisation's activities, leading to more open, honest and innovative activities and increases the level of freedom of its members, and also strengthens social ties" (Czajkowska 2014, pp. 229-230).

However, if the ultimate goal, which appears as a slightly utopian ideal - the creation of a culture of trust - is not achieved, it is still worth trying, because its very formation can become an important causative factor. We might then consider the spiral of trust, that is, the conjugated strengthening of individual trust variables (values of norms and formulas cultivating concern for "common good") and thus trust itself (Hejduk, Sankowska, Grudzewski 2007).

\section{References}

Babbie E. (2008), Podstawy badań społecznych, Warszawa, Wydawnictwo Naukowe PWN Barankiewicz, T. (2013), W poszukiwaniu modelu standardów etycznych administracji publicznej, Lublin, Wyd. KUL

Bibb, S., Kourdi, J. (2004), Trust matters - for organisational and personal success, New York, Palgrave

Blake R., Mouton J. (1964), The Managerial Grid: The Key to Leadership Exellence, Houston, Gulf Publishing Company

Brown J.A.C. (1962), Spolecæna psychologia przemystu, Warszawa, KiW

Ciborowski L. (2010), Wstę [in:] Prakseologiczne aspekty zarzadzania we wspótczesnych organizacjach publicznych, (Eds.) Kieżun W., Ciborowski L., Wołejszo J., Vol. I, Warszawa, AON

Czajkowska M. (2014), Kultura organizacyjna oparta na zaufaniu [in:] Metody zarzqdzania kulturq organizacyjna, (Eds.) Sułkowski Ł., Sikorski C., Warszawa, Difin

Czerniawski H. (1982), Kultura wspótdziałania pracownikón umysłowych w przemyśle, Warszawa, Książka i Wiedza 
Derdziuk Z., Obłucki A. (2008), Rzqdðić efektywnie. Pię́ strumieni sprawowania władży [in:] Administracja publiczna. Wyzwania w dobie integracji europejskiej, (Ed.) Czaputowicz J., Warszawa, Difin

Filipek A. (2014), Rola i znaczenie kultury bezpieczeństwa w s̀yciu człowieka, [in:] W spółczesne bezpieczeństwo i kultura bezpieczeństwa, (Eds.) Filipek A., Gałek B., Siedlce, Wydawnictwo Uniwersytetu Przyrodniczo-Humanistycznego

Frąckiewicz-Wronka A. (2015), Nowoczesne praywództwo w organizacjach publicznych [in:] Instrumentarium zarzqdzania publicznego, (Eds.) Kożuch B., Sułkowski Ł., Warszawa, Difin

Gadomska-Lila K. (2017), Dopasowanie organizacyjne. Aspekt strategii, kultury organizacyjnej i zarzqdzania zasobami ludzkimi, Warszawa, Difin

Grudzewski W.M., Hejduk I.K., Sankowska A., Wańtuchowicz M. (2007), Zarzqdzanie zaufaniem w przedsiebiorstwie, Warszawa, Difin

Hardin G. (1968), The Tragedy of the Commons, „Science”, No. 162

Hersey, P., Blanchard, K.H. (1982), Management of organizational, behaviour, New York, Prentice Hall

Jung C.G. (1997), Typy osobowości, Warszawa, PWN

Kieżun W. (2005), O sprawnq administracje publicznna, „Ius et Lex” No. 1(III)

Kotarbiński T. (1999), Dzieła wszystkie. Prakseologia. Cześć I, Wrocław-Warszawa-Kraków, Ossolineum

Kożuch B. (2011), Nanka o organizacii, Warszawa, CeDeWu

Kożuch B., Sienkiewicz-Małyjurek K. (2013), Mierz̨enie skuteczności wspótpracy międzyorganizacyjnej w zarzqdzaniu bezpieczeństwem publicznym, „Studia Ekonomiczne Uniwersytetu Ekonomicznego", nr 68

Kulesza M., Niziołek M. (2010), Etyka stu̇̀by publicznej, Warszawa, Wolters Kluwer

Likert R. (1976), New Patterns of Management, London, McGrow-Hill Books Company

Milewski R. (2006), Podstawy ekonomii, Warszawa, Wydawnictwo Naukowe PWN

Młodzik L. (2018a), Kultura współdziałania stużby ochrony bezpieczeństwa publicznego na praykeładzie funkcjonariuszy Nadodrzańskiego Oddziału Straży Granicznej, Zielona Góra, Oficyna Wydawnicza Uniwersytetu Zielonogórskiego

Młodzik L. (2018b), Zaufanie jako kluçowa wartość organizacji publicznych w swietle badań żotnierzy zawodowych Wojska Polskiego, „Marketing i Zarządzanie” nr 1 (51) [in print] 
Oleksyn T. (2016), Natura wartości i katalog wartości w zarzqdzaniu [in:] Zarzqudzanie respektujace wartości. Raport z badań, (Eds.) Herman A., Oleksyn T., Stańczyk I. Warszawa, Difin

Penc J. (2011), Kultura i etyka w organizacji. Aspekty pragmatyczne i strategiczne, Szczytno, Wyższa Szkoła Policji

Reddin W.J. (1970), Effective Management by Objectives, New York, McGraw-Hill Book Company

Ricci K. (2006), Management by trust, Canada, Citation Books

Sankowska A. (2011), Wplyw zaufania na zarzadzanie przedsiebiorstwem. Perspektywa wewnatrzorganizacyjna, Warszawa, Difin.

Schindler, P.L., Thomas C.C. (1993), The Structure of interpersonal trust in the workplace, „Psychological Reports” Vol. 72, Iss. 2

Sienkiewicz-Małyjurek, K. (2010), Rola samorzqdów lokalnych w kształtowaniu bezpieczeństwa publicznego, „Samorząd terytorialny” No. 7-8

Šmid W. (2003), Psychologia i socjologia zarzqdzania. Stownik terminów, Sosnowiec, Wyższa Szkoła Zarządzania i Marketingu

Sułkowski Ł. (2012), Epistemologia i metodologia zarzqdzania, Warszawa, PWE

Szaban J.M. (2011), Zarzqdzanie zasobami ludzkimi w biznesie $i$ w administracji publicznej, Warszawa, Difin

Sztompka P. (2005), Socjologia. Analiza spoteczeństwa, Kraków, Znak

Sztompka P. (2007), Zaufanie. Fundament spoleczeństwa, Kraków, Znak

Władek Z. (2016), Organizacja i zarzqdzanie w administracji publicznej. Zarys wykładu, Warszawa, Difin

Zarzqdzanie respektujace wartości. Raport z. badań (2016), (Eds.) Herman A., Oleksyn T., Stańczyk I., Warszawa, Difin 